\title{
Pterygoplichthys spp. (Siluriformes: Loricariidae) meal is suitable for the culture of Nile tilapia Oreochromis niloticus (Cichlidae) juveniles
}

\author{
Martha Patricia Cano-Salgado ${ }^{1}$ (i) Carlos Alfonso Álvarez-González ${ }^{2}$ (i) Rafael Martínez-García ${ }^{2^{*}}$ (i) \\ Emyr Saul Peña-Marin ${ }^{2,4}$ (i) Uriel Rodríguez-Estrada ${ }^{2,4}$ Everardo Barba Macias $^{1}$ (i) \\ Roberto Civera-Cerecedo ${ }^{3}$ (D) Ernesto Goytortua-Bores ${ }^{3}$ (i)
}

\footnotetext{
${ }^{1}$ Manejo Sustentable de Cuencas y zonas Costeras, Departamento de Ciencias de la Sustentabilidad. El Colegio de la Frontera Sur (ECOSUR), Villahermosa, Tabasco, Mexico.

${ }^{2}$ Laboratorio de Acuicultura Tropical, División Académica de Ciencias Biológicas, Universidad Juárez Autónoma de Tabasco (DACBiolUJAT), 86139, Villahermosa, Tabasco, Mexico. E-mail: biologomartinez@hotmail.com. *Corresponding author.

${ }^{3}$ Centro de Investigaciones Biológicas del Noroeste (CIBNOR), La Paz, Baja California Sur, Mexico.

${ }^{4}$ Cátedra-CONACyT, Ciudad de México, Mexico.
}

\begin{abstract}
We search for positive utility impact on the invasive species Pterygoplichthys spp. The optimal level of replacement of sardine meal (SM) by Pterygoplichthys spp. meal (PLM) in practical feeds for fry of Nile tilapia (Oreochromis niloticus) was evaluated. We evaluated six experimental diets: $50 \%$ PLM-50\% SM, 60\% PLM-40\% SM, 70\% PLM-30\% SM, 80\% PLM-20\% SM, 90\% PLM-10\% SM and $100 \%$ $P L M-0 \%$ SM. In a recirculation system, 270 sex-reversed tilapia fry were used $(0.7 \pm 0.1 \mathrm{~g})$. Diets were administered in triplicate and the experiment lasted 56 days with sampling every 14 days. There were no statistical differences in growth. At the end of the experiment, the SGR, $A D G, C F, W G, D F I, F C R$ and PER were determined without significant differences $(P>0.05)$ between treatments, but there was a tendency that could indicated higher WG and PER in the $90 \%$ PLM-10\% SM treatment $(93.56 \pm 0.43 \%$ and $8.44 \pm 1.18 \mathrm{~g}$, respectively). All survival rates were higher than $90 \%$ with no significant differences. Additionally, there were no statistical differences in the chemical composition of the whole fish, while apparent digestibility coefficients of protein (81-90\%) and lipids (87-93\%) also showed no significant differences. We concluded that $100 \%$ PLM can replace 100\% SM in feeding fry of O. niloticus without affecting their survival, growth or chemical composition or the apparent digestibility of nutrients.
\end{abstract}

Key words: apparent digestibility coefficient, growth parameters, protein, pterygoplichthys meal, replacement.

Farinha de Pterygoplichthys spp. (Siluriformes: Loricariidae) é adequado para a cultura da tilápia juvenil do Nilo Oreochromis niloticus (Cichlidae)

RESUMO: Buscamos por um impacto positivo de utilidade nas espécies invasoras como Pterygoplichthys spp. Foi avaliado o nível ótimo de substituição da farinha de sardinha (SM) pela farinha de Pterygoplichthys spp. (PML) em dietas práticas para tilápia do Nilo (Oreochromis niloticus). Foram utilizadas seis dietas experimentais; 50\% PLM-50\% SM, 60\% PLM-40\% SM, 70\% PLM-30\% SM, 80\% PLM-20\% SM, 90\% PLM-10\% SM e 100\% PLM-0\% SM. Em sistema de recirculação foram colocados 270 filhotes de tilápia machos (0.7 $\pm 0.1 \mathrm{~g}$ ). As dietas foram triplicadas, o experimento durou 56 dias com amostragem a cada 14 dias, não houve diferença estatística para o crescimento. No final do experimento, foram determinados $S G R, A D G, C F, W G, D F I, F C R$ e PER, não encontrando diferenças significativas (P> 0,05), embora tenha havido uma tendência indicando maior WG e PER na dieta 90\% PLM-10\% SM (93,56 \pm 0,43\% e 8,44 $\pm 1,18$ g). A sobrevida foi superior a 90\%, sem diferenças significativas. Além disso, não houve diferenças significativas na composição proximal de todo o peixe, enquanto o aparente coeficiente de digestibilidade de proteinas (81-90\%) e lipidios (87-93\%) também não mostrou diferenças significativas. Podemos concluir que o uso de $100 \%$ de farinha de Pterygoplichthys spp. pode substituir 100\% de farinha de sardinha na alimentação de jovens $O$. niloticus sem afetar a sobrevivência, o crescimento, a composição química e a digestibilidade aparente dos nutrientes.

Palavras-chave: coeficiente de digestibilidade aparente, parâmetros de crescimento, proteína, farinha de Pterygoplichthys, substituição.

\section{INTRODUCTION}

There is a fish group from the Loricaridae family and genus Pterygoplichthys present in southeast Mexico. These fish are an invasive species introduced as ornamental fish from different parts of the world and have presented very serious environmental problems, such as damage to local fisheries, species displacement, orographic impact and as vectors of non-native parasites (MENDOZA et al., 2009; ORFINGER et al., 2018). In Mexico, these species do not represent any economic value to fishermen and are not accepted as food by the general population, so research has been focused on obtaining 
various by-products for use as fertilizers, for human consumption and as fishmeal for feed; such utilization could control their invasion (GUERRA, 2008). Fishmeal is the by-product with a wider perspective because it is a product with high protein content (56-60\%) and has an adequate amino acid profile (ESCALERA et al., 2006).

Nile tilapia, Oreochromis niloticus, Linnaeus, 1758, are highly resistant to changes in environmental conditions and shows rapid growth, high productivity and good adaptation to captivity. Is well known that tilapia is an omnivorous species (MORALES, 1991), which allows a wide range of feed to be used for their growth. Tilapia is the most widely produced fish (ZHOU, 2019) and Mexico is one of the largest producers of tilapia in the Americas (FITZSIMMONS, 2000). However, as tilapia culture has increased, the demand for feed has also increased, raising the production costs by almost 50\% (EL-SAYED, 1999). The production of fish feed has traditionally been based on the use of fishmeal (sardine, anchovies, etc.), this being the main source of protein, with a suitable amino acid profile and a source of essential fatty acids, digestible energy, vitamins and minerals (TACON, 1993; ABDELGHANY, 2003), all of which makes fishmeal the most expensive ingredient in animal feed (PETERS et al., 2004). In this sense, several studies have been undertaken to achieve reductions in this ingredient through the use of alternative sources of protein. Worldwide efforts have been developed to assess the partial or total replacement of fishmeal by other ingredients, either from terrestrial animals or plant sources. Several alternative ingredients, such as terrestrial animal by-products, have been tested: feather meal, chicken viscera, cattle blood (PETERS et al., 2004), aquatic animals such as shrimphead meal, squid meal (ÁLVAREZ et al., 2001, OLIVEIRA et al., 2007), as well as those of plant origin, such as legume and cereal meals (BORGESON et al., 2006; GARDUÑO-LUGO et al., 2008), and the use of probiotics (LARA-FLORES et al., 2002) because of the omnivorous habit. However, their use depends largely on the nutritional value, quality, inclusion levels, availability and cost of each ingredient.

Aquaculture efforts should be focused on the use of local, non-human-food ingredients in order to reduce imported feed ingredients and so to ensure a sustainable aquaculture industry (TACON, 2020). Thus, the objective of this study was to evaluate six experimental diets, using as protein source the nonfood Pterygoplichthys spp. meal, on apparent digestibility and the growth, survival and chemical composition of juvenile Nile tilapia Oreochromis niloticus.

\section{MATERIALS AND METHODS}

\section{Fry collection}

Sex-reversed tilapia larvae were obtained from the Tropical Aquaculture Laboratory UJATDACBIOL, Villahermosa, Tabasco, Mexico.

Preparation of the Pterygoplichthys spp. meal (PLM) For meal preparation, 715 adults of Pterygoplichthys spp. (500-700 g) were collected from the El Chimal and El Susil lakes, Balancan, Tabasco, Mexico. Muscle was cut near the tail fin, then dried in an oven (Coriat, HC-35-D, Zapopan, Jalisco, Mexico) for $24 \mathrm{~h}$. Once dried, it was passed through a Wileytype mill (AHT Co, Philadelphia, PA, USA) and a 2-mm sieve to produce Pterygoplichthys spp. meal (PLM, 54\% protein). Samples were stored in plastic bottles and refrigerated for proximal chemical analysis.

\section{Formulation and manufacture of experimental diets}

Six experimental diets were formulated and manufactured. The Mixit-Win ${ }^{\circledR} 5.0$ software was used, considering the nutritional requirements of the species and the proximate composition of different ingredients, including PLM (AOAC, 1995).

For the manufacture of each diet the macro-ingredients were mixed in a rotary mixer (BATHAMMEX $^{\mathrm{MR}}$ 178716, Mexico) for $10 \mathrm{~min}$. Subsequently, the micro-ingredients were added and mixed for another $10 \mathrm{~min}$. Then, in a plastic container, liquid ingredients were mixed for $10 \mathrm{~min}$ to form an emulsion, which was added to the mixture of dry ingredients and mixing for $10 \mathrm{~min}$. Finally, $400 \mathrm{~mL}$ of water was added slowly to produce a paste, which was passed through a meat grinder (TORREYMR M-22R1, N.L., Mexico) to form pellets with a die of $0.45 \mathrm{~mm}$ in diameter, which were then were dried in an oven (CORIAT, HC-35-D, Zapopan, Jalisco, Mexico) for $12 \mathrm{~h}$ at $60{ }^{\circ} \mathrm{C}$. The pellets were ground and stored in refrigeration at $-20{ }^{\circ} \mathrm{C}$ until use.

\section{Experimental design}

Sardine meal (SM) was taken as the base for partial replacement of protein with PLM, from $50 \%$ to $60,70,80,90$ and $100 \%$, also varying the amount of sorghum meal and fish oil in order to obtain iso-lipidic and iso-proteinic diets (Table 1). The experiment was carried out in a recirculation system with 270 tilapia juveniles $(0.7 \mathrm{~g} \pm 0.1)$ 
Table 1 - Formulation and proximate analysis of the experimental diets.

1 Balanced Feeds Galmez, Villahermosa, Tabasco, Mexico; 2 Proteínas marinas y agropecuarias, S. A de C.V. Guadalajara, Jalisco, Mexico, 3 Lagunas Susil y el Chinal, Balancán, Tabasco, Mexico, 4 Sigma-Aldrich, Cat. 8020, 5 Pronat Ultra. Mérida, Yucatán, Mexico, 6 Almacenes Chedraui, Mexico, 7 Jalmek, Cat. 5260-05, 8 Vitamin premix (g/kg of premix): Vitamin A Acetate (Retinol), 0.086; Vitamin D3 (Cholecalciferol), 0.006; Vitamin E (Tocoferol), 5; Vitamin K Menadiona, 1; Thiamine (B1), 0.1; Riboflavin (B2), 0.4; Pyridoxine (B6), 0.3; DL-Pantothenic Acid, 2; Niacin (acid nicotinamide), 1; Biotin, 0.016; Inositol, 30; Cyanocobalamin (B12), 0.002; Folic Acid, 0.1; Vehicle (cellulose), 960, 9 Mineral premix (g/kg of premix): $\mathrm{CaCl}_{2} .2 \mathrm{H}_{2} \mathrm{O}, 257.5 ; \mathrm{MgSO}_{4} .7 \mathrm{H}_{2} \mathrm{O}, 149.14$; $\mathrm{ZnSO}_{4} .7 \mathrm{H}_{2} \mathrm{O}, 2.76 ; \mathrm{MnCl}_{2} .4 \mathrm{H}_{2} \mathrm{O}, 0.96 ; \mathrm{CuSO}_{4} .5 \mathrm{H}_{2} \mathrm{O}, 0.25 ; \mathrm{KI}, 0.00003 ; \mathrm{Na}_{2} \mathrm{SeO}_{3}, 0.0042 ; \mathrm{Na}_{2} \mathrm{HPO}_{4}, 571.58 ; \mathrm{FeSO}_{4} .7 \mathrm{H}_{2} \mathrm{O}, 17.88,10$ Rovimix ${ }^{\circledR} \mathrm{C}$-EC (Roche) active agent $35 \%$.

\begin{tabular}{|c|c|c|c|c|c|c|}
\hline $\begin{array}{l}\text { Ingredients } \\
\text { (g/100 g diet) }\end{array}$ & $\begin{array}{c}50 \% \text { PLM- } \\
50 \% \text { SM }\end{array}$ & $\begin{array}{c}60 \% \text { PLM- } \\
40 \% \text { SM }\end{array}$ & $\begin{array}{c}70 \% \text { PLM- } \\
30 \% \text { SM }\end{array}$ & $\begin{array}{c}80 \% \text { PLM- } \\
20 \% \text { SM }\end{array}$ & $\begin{array}{c}90 \% \text { PLM- } \\
10 \% \mathrm{SM}\end{array}$ & $\begin{array}{c}100 \% \text { PLM- } \\
0 \% \mathrm{SM}\end{array}$ \\
\hline Sardine meal & 15.80 & 12.90 & 9.49 & 6.29 & 3.17 & 0.00 \\
\hline Sorghum meal & 35.04 & 34.10 & 33.04 & 32.10 & 31.20 & 30.31 \\
\hline Pterygoplichthys meal & 20.66 & 23.90 & 27.89 & 31.88 & 35.87 & 39.99 \\
\hline Soybean meal & 20.00 & 20.64 & 21.17 & 21.38 & 21.49 & 21.50 \\
\hline Sardine oil & 2.00 & 2.00 & 2.00 & 2.00 & 2.00 & 2.00 \\
\hline Soybean lecithin & 1.92 & 1.88 & 1.83 & 1.76 & 1.70 & 1.62 \\
\hline Grenetin & 2.00 & 2.00 & 2.00 & 2.00 & 2.00 & 2.00 \\
\hline Chromic oxide & 1.00 & 1.00 & 1.00 & 1.00 & 1.00 & 1.00 \\
\hline Vitamin premix & 1.00 & 1.00 & 1.00 & 1.00 & 1.00 & 1.00 \\
\hline Mineral premix & 0.50 & 0.50 & 0.50 & 0.50 & 0.50 & 0.50 \\
\hline Vitamin C & 0.08 & 0.08 & 0.08 & 0.08 & 0.08 & 0.08 \\
\hline \multicolumn{7}{|c|}{ - } \\
\hline Moisture & $3.07 \pm 0.20$ & $3.09 \pm 0.24$ & $3.48 \pm 0.18$ & $3.72 \pm 0.05$ & $3.22 \pm 0.07$ & $3.29 \pm 0.08$ \\
\hline Ash & $9.71 \pm 0.09$ & $9.82 \pm 0.04$ & $9.87 \pm 0.04$ & $10.06 \pm 0.24$ & $9.82 \pm 0.06$ & $9.88 \pm 0.04$ \\
\hline Protein & $38.68 \pm 0.29$ & $39.52 \pm 0.22$ & $40.57 \pm 0.28$ & $41.39 \pm 0.19$ & $42.48 \pm 0.03$ & $42.52 \pm 0.15 b$ \\
\hline Ether extract & $7.90 \pm 0.39$ & $7.62 \pm 0.09$ & $6.99 \pm 0.05$ & $6.90 \pm 0.02$ & $6.13 \pm 0.20$ & $5.72 \pm 0.14 \mathrm{a}$ \\
\hline Fiber & $0.80 \pm 0.08$ & $0.68 \pm 0.06$ & $0.67 \pm 0.08$ & $0.77 \pm 0.21$ & $0.55 \pm 0.03$ & $0.69 \pm 0.05 \mathrm{ab}$ \\
\hline Nitrogen-free extract & $42.82 \pm 0.11$ & $42.36 \pm 0.24$ & $41.90 \pm 0.26$ & $40.88 \pm 0.38$ & $41.02 \pm 0.28$ & $41.19 \pm 0.26$ \\
\hline Energy $(\mathrm{Kcal} / \mathrm{g})$ & $4.53 \pm 0.32$ & $4.57 \pm 0.40$ & $4.38 \pm 0.13$ & $4.64 \pm 0.37$ & $4.23 \pm 0.14$ & $4.85 \pm 0.16$ \\
\hline
\end{tabular}

placed randomly in 18 tanks of $70 \mathrm{~L}$ for 56 days; each diet was evaluated in triplicate. Weight (g) and total length $(\mathrm{cm})$ were recorded every 14 days. Survival was determined daily. An average temperature (T) between 27.2 and $30.5{ }^{\circ} \mathrm{C}$ was maintained, dissolved oxygen (DO) ranged between 6.6 and $7.5 \mathrm{mg} / \mathrm{L}$ and $\mathrm{pH}$ ranged from 5.2 to 7.5 . These parameters were recorded daily with a YSI 85 handheld meter (for T and DO) (YSI, Ohio, USA) and a pH meter (HANNA HI 991001, Romania). Fish were fed three times per day $(9: 00,13: 00$, and 17:00 h) starting with 10\% of the biomass in each tank and then adjusting the ratio in terms of feed consumption.

\section{Proximal analysis}

At the end of the experiment, five fish per replicate were sampled for proximal chemical analysis of the whole fish. All samples were frozen at $-20^{\circ} \mathrm{C}$ and then lyophilized. Analyses were carried out in the Institutional Laboratory of the Colegio de la Frontera Sur, San Cristobal de las Casas Unit, Chiapas, according to the AOAC (1995).

\section{Apparent digestibility coefficient}

To determine the apparent digestibility of nutrients (protein and lipids), feces were collected three times a day, $1 \mathrm{~h}$ after each feeding, by siphoning. After collection, feces were frozen at $-20{ }^{\circ} \mathrm{C}$ for lyophilization. The lyophilized feces were analyzed to determine the concentration of proteins, lipids, dry matter and chromic oxide $\left(\mathrm{Cr}_{2} \mathrm{O}_{3}\right)$. For the determination of protein content, the micro Kjeldhal method was used according AOAC (1995) and for lipids the Bligh, Dyer (1959) technique using a SoxletAvanti FOSS TECATOR (AB, BOX 70, S-26321, Höganäs, Sweden). To determine the chromic oxide, the FURUKAWA et al. (1966) technique was used. The analyses were carried out in the Aquaculture Nutrition Laboratory of the Center of Biological Research of the Northwest, S.C. La Paz B. C. S., Mexico. 


\section{Statistical analysis}

To determine significant differences among the treatments and growth variables (total length and weight) and survival, a test for normality (KruskalWallis test) and Levene's test for homogeneity of variance were first applied and, if these postulates were met, a one-way ANOVA was used, and finally the Tukey test was applied to determine the differences among treatments. Growth rates, feed quality, proximal chemicals of the fish, and apparent digestibility (protein and lipids) of the treatments were compared by using the nonparametric test of Kruskal-Wallis and, where significant differences were found, the Nemenyi test was applied. All statistical tests were performed with a significance level of $\alpha=0.05$ using STATISTICA v. 8 software (Statsoft, Inc., Tulsa, OK, USA).

\section{RESULTS AND DISCUSSION}

Results of growth in weight and total length over 56 days showed no significant differences $(\mathrm{P}>0.05)$ among treatments, values ranged from $9.07 \pm 0.39 \mathrm{~g}$ in $60 \% \mathrm{PLM}-40 \% \mathrm{SM}$ treatment to $10.76 \pm 1.04 \mathrm{~g}$ in $90 \%$ PLM-10\% SM treatment for weight and $7.57 \pm 0.23 \mathrm{~cm}$ in $70 \%$ PLM-30\% SM treatment to $8.17 \pm 0.32 \mathrm{~cm}$ in $90 \%$ PLM-10\% SM treatment (Table 2).

There were no significant differences $(\mathrm{P}<$ 0.05 ) in any of the rates of growth or feed efficiency among treatments (Table 3). Regardless of this, condition factor $(\mathrm{CF})$ and weight gain (WG) in the diets with 90\% PLM-10\% SM and 80\% PLM-20\% SM both showed the highest values, of $1.97 \pm 0.06$ and $93.56 \pm 0.43 \%$, and $1.97 \pm 0.04$ and $93.04 \pm 1.02 \%$, respectively. For the feed conversion ratio (FCR) and the protein efficiency ratio (PER), despite no statistical differences being expressed among treatments, fish fed with the 90\% PLM-10\% SM diet showed the highest values $(0.28 \pm 0.04 \mathrm{~g}$ and $8.44 \pm 1.18 \mathrm{~g}$, respectively), followed by treatment $80 \%$ PLM-20\% $\mathrm{SM}$, of $0.31 \pm 0.08 \mathrm{~g}$ and $7.87 \pm 1.87 \mathrm{~g}$, respectively (Table 3 ). In the case of survival, differences were not significant $(\mathrm{P}>0.05)$, although it should be mentioned that fish fed with the $90 \%$ PLM-10\% SM diet had the highest survival rate $(97.7 \%)$.

In relation to the body chemical composition of tilapia fry there was no statistical significance differences $(\mathrm{P}>0.05)$ between any of the treatments; however, the lipid content varied as did the protein content: it was similar between the treatments although there was a slight increase in the case of the $90 \%$ PLM-10\% SM diet (Table 4).

For the apparent digestibility coefficients (ADCs) of protein and lipids, there were no significant differences $(\mathrm{P}>0.05)$ between experimental diets. Apparent protein digestibility ranged between 81.4 and $89.5 \%$, showing an increase as the inclusion level of PLM increased, while the ADCs of lipids was similar to those of protein but with higher values, ranging between 87.13 and $93.49 \%$ in relation to the increase in PLM in the diets. In this way, it was observed that the $90 \%$ PLM-10\% SM treatment showed the highest ADC of lipids, of $93.49 \%$ (Table 4 ).

Table 2 - Weight $(\mathrm{g})$ and total length $(\mathrm{cm})$ of tilapia fry fed with experimental diets (mean $\pm \mathrm{SD})$.

\begin{tabular}{|c|c|c|c|c|c|c|}
\hline Day & $\begin{array}{c}50 \% \text { PLM- } \\
50 \% \mathrm{SM}\end{array}$ & $\begin{array}{c}60 \% \text { PLM- } \\
40 \% \mathrm{SM}\end{array}$ & $\begin{array}{c}70 \% \text { PLM- } \\
30 \% \mathrm{SM}\end{array}$ & $\begin{array}{c}80 \% \text { PLM- } \\
20 \% \mathrm{SM}\end{array}$ & $\begin{array}{c}90 \% \text { PLM- } \\
10 \% \mathrm{SM}\end{array}$ & $\begin{array}{c}100 \% \text { PLM- } \\
0 \% \mathrm{SM}\end{array}$ \\
\hline 0 & $0.71 \pm 0.00$ & $0.69 \pm 0.00$ & $0.70 \pm 0.05$ & $0.68 \pm 0.02$ & $0.69 \pm 0.03$ & $0.74 \pm 0.03$ \\
\hline 14 & $1.61 \pm 0.03$ & $1.50 \pm 0.06$ & $1.57 \pm 0.12$ & $1.60 \pm 0.05$ & $1.60 \pm 0.03$ & $1.54 \pm 0.09$ \\
\hline 28 & $3.03 \pm 0.09$ & $2.90 \pm 0.14$ & $3.08 \pm 0.14$ & $3.04 \pm 0.22$ & $3.02 \pm 0.17$ & $2.96 \pm 0.20$ \\
\hline 42 & $6.13 \pm 0.44$ & $5.95 \pm 0.62$ & $5.94 \pm 0.34$ & $6.11 \pm 0.72$ & $6.37 \pm 0.38$ & $6.08 \pm 0.59$ \\
\hline 56 & $9.57 \pm 0.80$ & $9.07 \pm 0.39$ & $9.28 \pm 0.83$ & $10.02 \pm 1.55$ & $10.76 \pm 1.04$ & $9.96 \pm 1.04$ \\
\hline \multicolumn{7}{|c|}{--1--- } \\
\hline Day & $\begin{array}{c}50 \% \text { PLM- } \\
50 \% \mathrm{SM}\end{array}$ & $\begin{array}{c}60 \% \text { PLM- } \\
40 \% \mathrm{SM}\end{array}$ & $\begin{array}{c}70 \% \text { PLM- } \\
30 \% \text { SM }\end{array}$ & $\begin{array}{c}80 \% \text { PLM- } \\
20 \% \text { SM }\end{array}$ & $\begin{array}{c}90 \% \text { PLM- } \\
10 \% \mathrm{SM}\end{array}$ & $\begin{array}{c}100 \% \text { PLM- } \\
0 \% \mathrm{SM}\end{array}$ \\
\hline 0 & $3.42 \pm 0.26$ & $3.38 \pm 0.03$ & $3.43 \pm 0.04$ & $3.38 \pm 0.05$ & $3.37 \pm 0.03$ & $3.45 \pm 0.07$ \\
\hline 14 & $4.61 \pm 0.05$ & $4.53 \pm 0.04$ & $4.44 \pm 0.22$ & $4.65 \pm 0.08$ & $4.59 \pm 0.04$ & $4.49 \pm 0.07$ \\
\hline 28 & $5.78 \pm 0.03$ & $5.62 \pm 0.05$ & $5.74 \pm 0.10$ & $5.72 \pm 0.11$ & $5.76 \pm 0.16$ & $5.66 \pm 0.12$ \\
\hline 42 & $7.61 \pm 1.04$ & $6.91 \pm 0.18$ & $6.83 \pm 0.10$ & $7.00 \pm 0.30$ & $7.06 \pm 0.16$ & $6.99 \pm 0.14$ \\
\hline 56 & $7.67 \pm 0.12$ & $7.80 \pm 0.00$ & $7.57 \pm 0.23$ & $7.97 \pm 0.40$ & $8.17 \pm 0.32$ & $7.90 \pm 0.26$ \\
\hline
\end{tabular}


Table 3 - Growth variables and survival percentage of tilapia fry fed with experimental diets for 56 days (mean \pm SD) and feed efficiency of tilapia fry fed with experimental diets for 56 days (mean \pm SD).

\begin{tabular}{|c|c|c|c|c|c|c|}
\hline Indexes & $\begin{array}{c}50 \% \text { PLM- } \\
50 \% \mathrm{SM}\end{array}$ & $\begin{array}{c}60 \% \text { PLM- } \\
40 \% \mathrm{SM}\end{array}$ & $\begin{array}{c}70 \% \text { PLM- } \\
30 \% \mathrm{SM}\end{array}$ & $\begin{array}{c}80 \% \text { PLM- } \\
20 \% \mathrm{SM}\end{array}$ & $\begin{array}{c}90 \% \text { PLM- } \\
10 \% \mathrm{SM}\end{array}$ & $\begin{array}{c}100 \% \text { PLM- } \\
0 \% \mathrm{SM}\end{array}$ \\
\hline $\begin{array}{l}\text { Specific Growth Rate } \\
(\% / \text { day })\end{array}$ & $4.64 \pm 0.15$ & $4.59 \pm 0.10$ & $4.61 \pm 0.25$ & $4.77 \pm 0.27$ & $4.90 \pm 0.12$ & $4.65 \pm 0.15$ \\
\hline $\begin{array}{l}\text { Average Daily Gain } \\
\text { (g/day) }\end{array}$ & $0.16 \pm 0.01$ & $0.15 \pm 0.01$ & $0.15 \pm 0.02$ & $0.17 \pm 0.03$ & $0.18 \pm 0.02$ & $0.17 \pm 0.02$ \\
\hline Condition Factor & $2.12 \pm 0.10$ & $1.91 \pm 0.08$ & $2.14 \pm 0.10$ & $1.97 \pm 0.04$ & $1.97 \pm 0.06$ & $2.02 \pm 0.03$ \\
\hline Weight Gain (\%) & $92.55 \pm 0.62$ & $92.32 \pm 0.40$ & $92.40 \pm 1.02$ & $93.05 \pm 1.02$ & $93.56 \pm 0.43$ & $92.57 \pm 0.63$ \\
\hline Survival (\%) & $86.67 \pm 11.54$ & $86.67 \pm 9.43$ & $82.22 \pm 3.85$ & $95.56 \pm 7.70$ & $97.78 \pm 3.85$ & $93.33 \pm 6.67$ \\
\hline \multicolumn{7}{|c|}{ 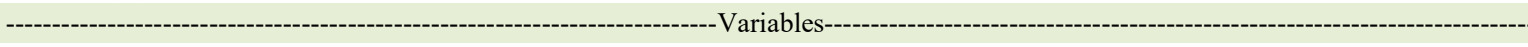 } \\
\hline Daily Feed Intake & $0.05 \pm 0.01$ & $0.05 \pm 0.01$ & $0.05 \pm 0.00$ & $0.05 \pm 0.01$ & $0.05 \pm 0.00$ & $0.05 \pm 0.01$ \\
\hline Feed Conversion Rate & $0.36 \pm 0.03$ & $0.38 \pm 0.02$ & $0.40 \pm 0.05$ & $0.31 \pm 0.08$ & $0.28 \pm 0.04$ & $0.32 \pm 0.02$ \\
\hline $\begin{array}{l}\text { Protein Efficiency } \\
\text { Ratio }\end{array}$ & $7.08 \pm 0.60$ & $6.57 \pm 0.47$ & $6.23 \pm 0.94$ & $7.87 \pm 1.87$ & $8.44 \pm 1.18$ & $7.29 \pm 0.51$ \\
\hline
\end{tabular}

In the absence of significant differences among treatments by replacing SM at levels above $90 \%$ PLM it was observed that the growth of tilapia was suitable, since PLM has good levels of protein (54\%) although slightly less than SM (65-70\%) besides having an adequate profile of amino acids and fatty acids needed for growth (ESCALERA et al.,, 2006). In this same way, OLIVEIRA et al. (2007) used waste by-products of the shrimp industry as protein sources for tilapia, showing CFs and WGs of 0.13 and $0.16 \mathrm{~g}$, respectively which turned out to be lower than those obtained in our study $(0.15 \pm 0.02$ and to $0.18 \pm 0.02 \mathrm{~g}$ ) when evaluating levels of inclusion of $0 \%, 33.3 \%, 66.6 \%$ and $100 \%$ of shrimphead silage meal. MEJRI et al. (2019) evaluated the use of an invasive species, white sucker (Catostomus commersonii) as fish meal ingredient for the growth of walleye (Sander vitreus) finding better growth with the experimental fish meal diet, probably due to the selective incorporation of oleic acid, which was greater in juveniles fed with white sucker fish meal. The evaluation by ABARRA et al. (2017), who evaluated fishmeal replacement by processed knife fish (Chitala ornata) meal in diets of $O$. niloticus, finding increases in average percentage WG, SGR and feed intake up to replacement levels of $75 \%$. However, LLANES et al. (2006) utilizing fish silage (two wet diets containing $25 \%$ raw protein) in fingerlings of red tilapia $(O$. mossambicus x O. niloticus) of initial weight $3.5 \mathrm{~g}$ reported a high survival rate (94.6\%) similar to this research $(97.78 \%$ ), although the parameters SGR and PER (2.36\%/day and $1.05 \mathrm{~g}$, respectively) were lower than those found in our study $(4.90 \%$ /day and
$8.44 \pm 1.18$ g respectively), which shows that for these species the use of PLM is more efficient than silages because during its preparation the main nutrients (protein, lipids and carbohydrates) are hydrolyzed, so releasing monomers (free amino acids, fatty acids, and monosaccharides), which can saturate the uptake channels and limit the digestibly (PARIN \& SUGARRAMURDI, 1977).

Also, the quality of the manufactured fish silage can be affected in some cases by the type of fermentation, decreasing enzymatic activity and the assimilation of protein by juvenile tilapia (ELSAYED, 1999). This same happens when using poultry by-products (hydrolyzed feather meal) and mixtures of these and pig meal as alternative protein sources for tilapia, where growth rates SGR, FCR and PER were decreased (3.21\%/day, 1.64 and 2.2, respectively) in comparison with our results using $\operatorname{PLM}(4.9 \%$ /day, 0.28 and $8.44 \pm 1.18 \mathrm{~g}$, respectively) as reported by HERNANDEZ et al. (2009).

A high inclusion of PLM in balanced feed for O. niloticus is considered suitable in terms of growth; this was corroborated by analysis of the chemical composition of the whole fish at the end of the experiment, where it was observed that as the inclusion level of PLM increased the level of body lipids in the tilapia decreased, indicating that this species assimilates PLM optimally. Fish with low lipid levels (from 15.2 to $15.7 \%$ ) were obtained when using substitutions of 80 to $100 \%$ of PLM meal, compared to those resulting from lower inclusions ( 16.6 to $18.9 \%$ with inclusions of 50 to $70 \%$ ) However, OLIVEIRA et al. (2007) and HERNANDEZ et al. 
Table 4 - Chemical composition (\% dry matter) of whole fish of juveniles of tilapia fed with experimental diets (mean \pm SD) and apparent digestibility coefficients (ADCs) of dry matter, protein, and lipids of the experimental diets (mean \pm SD).

\begin{tabular}{|c|c|c|c|c|c|c|}
\hline $\begin{array}{l}\text { Chemical Analysis } \\
\text { (g/100 g BS) }\end{array}$ & $\begin{array}{c}50 \% \text { PLM- } \\
50 \% \mathrm{SM}\end{array}$ & $\begin{array}{c}60 \% \text { PLM- } \\
40 \% \mathrm{SM}\end{array}$ & $\begin{array}{c}70 \% \text { PLM- } \\
30 \% \mathrm{SM}\end{array}$ & $\begin{array}{c}80 \% \text { PLM- } \\
20 \% \text { SM }\end{array}$ & $\begin{array}{c}90 \% \text { PLM- } \\
10 \% \mathrm{SM}\end{array}$ & $\begin{array}{c}100 \% \text { PLM- } \\
0 \% \mathrm{SM}\end{array}$ \\
\hline Moisture & $7.05 \pm 0.48$ & $7.37 \pm 0.12$ & $7.00 \pm 0.33$ & $6.88 \pm 0.15$ & $7.40 \pm 0.29$ & $7.18 \pm 0.54$ \\
\hline Ash & $14.75 \pm 0.08$ & $14.82 \pm 0.32$ & $15.21 \pm 0.41$ & $15.21 \pm 0.32$ & $14.84 \pm 0.16$ & $15.24 \pm 0.45$ \\
\hline Crude protein & $53.48 \pm 2.58$ & $54.23 \pm 0.51$ & $52.60 \pm 3.73$ & $53.93 \pm 0.77$ & $55.74 \pm 1.66$ & $54.89 \pm 1.23$ \\
\hline Ether extract & $18.87 \pm 1.84$ & $17.65 \pm 1.36$ & $16.57 \pm 0.74$ & $15.18 \pm 1.40$ & $15.67 \pm 0.93$ & $15.27 \pm 0.30$ \\
\hline Carbohydrates & $5.82 \pm 1.52$ & $5.92 \pm 1.42$ & $8.60 \pm 3.77$ & $8.78 \pm 1.00$ & $6.33 \pm 1.13$ & $7.39 \pm 1.79$ \\
\hline Energy $(\mathrm{Kcal} / \mathrm{g})$ & $4.97 \pm 0.14$ & $5.92 \pm 1.42$ & $4.86 \pm 0.07$ & $4.81 \pm 0.05$ & $4.82 \pm 0.05$ & $4.77 \pm 0.06$ \\
\hline \multicolumn{7}{|c|}{ 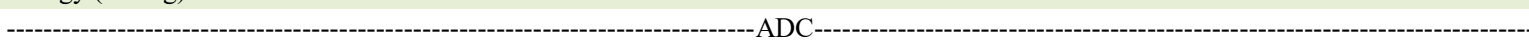 } \\
\hline Dry matter & $59.90 \pm 2.87$ & $62.83 \pm 4.24$ & $69.07 \pm 4.38$ & $68.10 \pm 1.97$ & $67.29 \pm 0.56$ & $67.82 \pm 5.08$ \\
\hline Protein & $81.41 \pm 0.78$ & $84.15 \pm 3.23$ & $87.43 \pm 2.90$ & $89.20 \pm 1.46$ & $88.99 \pm 0.55$ & $89.56 \pm 1.40$ \\
\hline Lipids & $88.89 \pm 1.75$ & $87.13 \pm 1.54$ & $90.48 \pm 2.55$ & $90.10 \pm 2.17$ & $93.49 \pm 0.57$ & $89.50 \pm 0.84$ \\
\hline
\end{tabular}

(2009) reported low levels of body lipids in juvenile tilapia $(5.07,4.36$ and $5.11 \% ; 6.3,7.5,5.9$ and $4.3 \%$, respectively) when using poultry by-products (ensilages with inclusion levels of $0,33.3,66.6 \%$ ) and fish by-products (ensilages with inclusion levels of 100 and $30 \%$ ). These differences in quantities of body lipids when using poultry by-products and fish silage could be due to the manufacturing process and type of raw material used in the production of the silage (whole fish, parts or debris), since the acidic substances or microorganisms added to perform the hydrolysis reduce the amount of lipids in the silage by metabolic oxidation, so that elaboration with these substances produce diets low in fat (BELLO, 1997). In our case, could be possible that the high lipid content was due to the manufacturing process, we did not separated fat from the PLM meal. However, this did not affect the growth of the tilapia and therefore, from the point view of shelf life and flavor, the lower the level of body lipids (in fillets or whole body), the better the quality with regard to storage and consumption of the product.

If the ADCs of nutrients are considered together with the chemical analysis of the whole fish, this will allow a higher estimation of the nutritive value of protein sources in diets for fish (KÖPRÜCÜ et al., 2005; MOHANTA et al., 2006). In this regard, the ADCs of dry matter (60-67\%), protein (81-89\%), and lipids (89-93\%) using PLM were increased as the inclusion level of meal increased, the ADCs of protein being within the ranges mentioned by CHO et al. (1990) and AKSNES and OPSTVEDT (1998) as being suitable for feeding fish. Thus the values obtained were high when using PLM, so that differences in the coefficients of apparent digestibility for protein ingredients may vary depending on the type of ingredient used in the replacement, its level of substitution, chemical composition and origin, and the processing of ingredients used and the methods of collection of feces (KÖPRÜCÜ et al., 2005; GABER et al., 2006). In this same sense, the ADCs obtained in this study corroborate the possibility of using substitutions of $90-100 \%$ of SM by PLM by presenting high values and a high content of corporal protein (55$56 \%$ ), indicating that the digestion, retention and use of PLM protein is adequate in juvenile tilapia.

The above results show that, despite several alternative protein sources (marine by-products and land animals such as poultry) showing good results in the growth and development of tilapia, there are still limitations on the availability (collection of wet ensilage and shrimp industry by-products, poultry by-products, meat and bone, blood, etc., as well as of seeds and leaves of plants) and processing of raw materials to obtain high-quality protein, coupled with the lack of some essential amino acids and, in some cases, the need to use ingredients or substances that act as attractors to improve the palatability of the diet (BORGESON et al., 2006).

Pterygoplichthys meal is considered a good ingredient, in future fat shoud be separated from PLM in order to have a better understanding of the protein replacement, replacing SM without having to include palatable, attractive substances or additional essential amino acids in the formulations, since the ingredient has the nutritional and biochemical characteristics necessary to meet the of protein and amino acid requirements of tilapia (ESCALERA et al., 2006). 
However, the disadvantage presented in the preparation of PLM lies in the collection of Pterygoplichthys spp., since despite being considered a highly invasive species introduced into the country several decades ago by the aquarium industry, its availability in the aquatic environments where it is found is currently unknown, so there are no records of the volume of its total catch or the feasibility of creating a sustainable fishery for its use in the production of feed for aquatic organisms. Therefore, it is necessary to carry out short-term studies referring to catch volumes, to determine whether it can be considered as a fish resource and thus be utilized not only as fishmeal but with the aggregate value as hydrolyzed or ensilaged feed in the aquaculture or other industries (MENDOZA et al., 2009).

It is important to point out that the production of fishmeal for use in aquaculture worldwide has been increasing, as has its cost (BORGESON et al., 2006); however, the trend in production for future years shows a decrease due to various factors, including climatic phenomena (El Niño and La Niña), pollution, and over exploitation of fishery resources, etc. (PETERS et al., 2004). Despite the great developments in aquaculture in the last two decades, the use of fishmeal has not increased substantially, because its inclusion in diets has decreased with the current tendency of replacing it with other meal (animal and plants) of similar nutritional quality to that of fishmeal but with lower costs (FENUCCI et al., 2007; GONZALEZ et al., 2007).

Under this scenario, it is necessary to seek out new alternative sources of protein that cover the requirements of protein, amino acids and essential fatty acids for the proper functioning and development of aquaculture species such as $O$. niloticus. This omnivorous species allows and facilitates the use of a wide range of ingredients in the formulation of diets, as this study has shown by the use of PLM, but can also take advantage of industrial alternatives such as hydrolysates, ensilages and attractors that can be manufactured with lower requirements in terms of raw materials than that of SM and consequently at lower cost.

\section{CONCLUSION}

Finally, this study showed that Pterygoplichthys spp. meal is a good ingredient that can be substituted at up to $90 \%$ without affecting the weight gain, feed conversion or protein efficiency in juveniles of $O$. niloticus.

\section{ACKNOWLEDGMENTS}

This research was supported by the National Council for Science and Technology and the Tropical Aquaculture Laboratory of the UJAT-DACBIOL, Villahermosa, Tabasco, Mexico.

\section{DECLARATION OF CONFLICT OF INTEREST}

All the authors declare no conflicts of interest. The founding sponsors had no role in the design of the study; in the collection, analysis, or interpretation of data; in the writing of the manuscript; nor in the decision to publish the results.

\section{AUTHORS' CONTRIBUTIONS}

All authors contributed equally to the conception and writing of the manuscript. All authors critically revised the manuscript and approved the final version.

\section{BIOETHICS AND BIOSECURITY COMMITTEE APPROVAL}

Fish were handled in accordance with the Declaration of Helsinki and the Norma Oficial Mexicana approved by the Secretaría de Agricultura, Ganadería, Desarrollo Rural, Pesca y Alimentación (NOM-062-ZOO-1999).

\section{REFERENCES}

ABARRA, S. T., et al. Replacement of fishmeal with processed meal from knife fish Chitala ornate in diets of juvenile Nile tilapia Oreochromis niloticus. Aquaculture Reports, v.5, p.76-83, 2017. Available from: <https://doi.org/10.1016/j.aqrep.2017.01.001>. Accessed: Jun. 9, 2018. doi: 10.1016/j.aqrep.2017.01.001.

ABDELGHANY A. Partial and complete replacement of fish meal with gambusia meal in diets for red tilapia Oreochromis niloticus X O. mossambicus. Aquaculture Nutrition. v.9, p.145-154, 2003. Available from: $<$ https://doi.org/10.1046/j.1365-2095.2003.00234. $\mathrm{x}>$.Accessed: Jun. 9, 2018. doi: 10.1046/j.1365-2095.2003.00234.x.

AKSNES A; OPSTVED J. Content of digestible energy in fish feed ingredients determined by the ingredient-substitution method. Aquaculture, v.161, p.45-53, 1998. Available from: $<$ https://doi. org/10.1016/S0044-8486(97)00255-X>. Accessed: Jun. 9, 2018. doi: 10.1016/S0044-8486(97)00255-X.

ASSOCIATION OF OFFICIAL ANALYTICAL CHEMISTS (AOAC). Official Methods of Analysis of the Association of Official Analytical Chemist, 16th edn. Washington, DC, USA; 1995. 265p.

BELLO, R. Experiencias con ensilado de pescado en Venezuela. In: Tratamiento y utilización de residuos de origen animal, pesquero y alimenticio en la alimentación animal. V, F. and $\mathrm{M}$, S. editors., Estudio FAO Producción y Sanidad Animal. Roma, Italia. 1997. Cap.1, p.1-14. Available from: <http://www.fao.org/ ag/aga/agap/frg/APH134/cap1.htm>. Accessed: Jun. 9, 2018.

BLIG, E. G., et al. A rapid method of total lipid extraction and purification. Canadian Journal of Biochemistry and Physiology, 
v.37: n.8, p.911-917, 1959. Available from: <https://www nrcresearchpress.com/doi/10.1139/o59-099\#.XtVItjr0k2w>. Accessed: Jun. 9, 2018. doi: 10.1139/o59-099\#.XtVItjr0k2w.

BORGESON, T. L., et al. Effect of replacing fishmeal and oil with simple or complex mixtures of vegetable ingredients in diets fed to Nile Tilapia (Oreochromis niloticus). Aquaculture Nutrition, v.12, p.141-149, 2006. Available from: <https://doi.org /10.1111/j.1365-2095.2006.00394.x>. Accessed: Jun. 9, 2018. doi: 10.1111/j.1365-2095.2006.00394.x

CHO, C. Y., et al. Nutritional energetics in fish: energy and protein utilization in rainbow trout (Salmo gairdneri). World Reviews in Nutrition Dietary, v.61, p.132-172, 1990. Available from: $<$ https://doi.org/10.1159/000417529>. Accessed: Jun. 9, 2018. doi: $10.1159 / 000417529$.

EL-SAYED, A. F. M. Alternative dietary protein sources for farmed tilapia, Orechromis spp. Aquaculture. v.179:149 n.168, 1999. Available from: <https://doi.org/10.1016/S0044-8486(99)001593>. Accessed: Jun. 9, 2018. doi: 10.1016/S0044-8486(99)00159-3.

ESCALERA, E., et al. Caracterización fisicoquímica y alternativas de utilización del Plecostomus spp. en la presa El Infiernillo. IPN-CIIDIR Michoacán. 2006. 33p.

FENUCCI, J., et al. Manual de ingredientes proteicos y aditivos empleados en la formulacion de alimentos balanceados para camarones peneidos. In: García Galano $\mathrm{T}$, et al. editors. Universidad Nacional de Mar del Plata, Argentina, Mar de Plata Argentina, 2007, 263p.

FITZSIMMONS, K. Tilapia aquaculture in Mexico. In: Costa-Pierce BA, Rakocy JE, editors. Tilapia aquaculture in the americas, Vol.2. The World Aquaculture Society, Louisiana, 2000. p.171-183.

FURUKAWA, A., et al. On the acid digestion method for the determination of chromic oxide as an index substance in the study of digestibility of fish feed. Bulletin of the Japanese Society of Science and Fisheries. v.32. n.6-8. 1966. Available from: $<$ https:// doi.org/10.2331/suisan.32.502>. Accessed: Jun. 9, 2018. doi: $10.2331 /$ suisan.32.502.

GABER, M., et al. Partial and complete replacement of fish meal by broad bean meal in feeds for Nile Tilapia, Orechromis niloticus, L., fry. Aquaculture Research. v.37, p.986-993, 2006. Available from: $\quad<$ https://doi.org/10.1111/j.1365-2109.2006.01517.x>. Accessed: Jun. 9, 2018. doi: 10.1111/j.1365-2109.2006.01517.x.

GARDUÑO, L., et al. Potential of the use of peanut (Arachis hypogaea) leaf meal as a partial replacement for fish meal in diets for Nile tilapia Oreochromis niloticus L. Aquaculture Research, v.39, p.1299-1306, 2008. Available from: <https://doi.org/10.1 111/j.1365-2109.2008.01995.x>. Accessed: Jun. 9, 2018. doi: 10.1111/j.1365-2109.2008.01995.x.

GONZALEZ, D., et al. Estudios preliminares en la formulación de dietas para camarón blanco (Litopenaeus schmitti) utilizando ensilado de pescado. Revista Científica, v.17, n.2, p.166-172, 2007. Available from: $<\mathrm{http}$ ://ve.scielo.org/scielo.php?script $=$ sci arttext\&pid=S0798-22592007000200010>. Accessed: Jun. 9, 2018.

GUERRA, G. J. Efecto de biofertilizantes y abonos orgánicos en la producción de fresa (Fragaria xananassa Duch.). 2008. Master Thesis. IPN/CIIDIR. Jiquilpan, Michoacán. Available from: $<$ https:// tesis.ipn.mx/handle/123456789/18985>. Accessed: Jun. 9, 2018.
HERNANDEZ, C. et al. Complete replacement of fish meal by porcine and poultry by-product meals in practical diets for fingerling Nile tilapia Oreochromis niloticus: digestibility and growth performance. Aquaculture nutrition, v.16, p.44-53, 2009. Available from: <https://doi.org/10.1111/j.1365-2095.2008.00639. x>.Accessed: Jun. 9, 2018. doi: 10.1111/j.1365-2095.2008.00639.x.

KÖPRÜCÜ, K., et al. Apparent digestibility of select feed ingredients for Nile tilapia (Oreochromis niloticus). Aquaculture, v.25 p.308-316, 2005. Available from: <https://doi.org/10.1016/j. aquaculture.2004.12.003>. Accessed: Jun. 9, 2018. doi: 10.1016/j. aquaculture. 2004.12.003.

LARA-FLORES, M., et al. Avances en la utilización de probióticos como promotores de crecimiento en tilapia nilótica. In: In CruzSuárez LE, et al. editors. Avances en Nutrición Acuícola. Memorias del VI Simposium Internacional de Nutrición Acuícola. México; 2002 p.335-345.

LLANES-IGLESIAS J. E., et al. Producción de alimento húmedo a partir de ensilados de pescado para la alimentación de tilapia roja (Oreochromis mossambicus x O. niloticus). Revista Aquatic, v.25, p.16-21, 2006. Available from: <http://www.revistaaquatic.com/ aquatic/art.asp?t=p\&c=204>. Accessed: Jun. 9, 2018.

MEJRI, S., et al. Novel feed from invasive species is beneficial to Walleye aquaculture. American Fisheries Society, v.81, p.312, 2019. Avaliable from: <https://doi.org/10.1002/naaq.10063>. Accesseed: Jan. 11, 2021. doi: 10.1002/naaq.10063.

MENDOZA, R., et al. Invasión de plecostomus en la presa El Infiernillo, México: análisis de efectos socioeconómicos (relato de dos invasores). In: Alfaro, R.E.M., et al. editors. Capitulo 5. Directrices trinacionales para la evaluación de riesgos de las especies acuáticas exóticas invasoras. Casos de prueba para el pez cabeza de serpiente (Channidae) y el pleco (Loricariidae) en aguas continentales de América del Norte. Comisión para la Cooperación Ambiental, Montreal (Quebec) Canadá. 2009b. p.51-59.

MOHANTA, K., et al. Apparent protein, lipid and energy digestibility coefficients of some commonly used feed ingredients in formulated pelleted diets for silver barb, Puntius gonionotus. Aquaculture Nutrition. v.12, p.211-218, 2006. Available from: $<$ https://doi.org/10.1111/j.1365-2095.2006.00403.x>. Accessed: Jun. 9, 2018. doi. 10.1111/j.1365-2095.2006.00403.x.

MORALES, D. La tilapia en México: Biología, cultivo y pesquerías. AGT S.A. México. 1991. 153p.

OLIVEIRA-CAVALHEIRO, J., et al. Utilization of shrimp industry waste in the formulation of tilapia (Oreochromis niloticus Linnaeus) feed. Bioresources Technology. v.98, p.602-606, 2007. Available from: <https://doi.org/10.1016/j.biortech.2006.02.018>. Accessed: Jun. 9, 2018. doi. 10.1016/j.biortech.2006.02.018.

ORFINGER, A. B., et al. The Global Invasion of the Suckermouth Armored Catfish Genus Pterygoplichthys (Siluriformes: Loricariidae): Annotated List of Species, Distributional Summary, and Assessment of Impacts. Zoologic Studies. v.57, n.7. 2018. Available from: <https://doi.org/10.6620/ZS.2018.57-07>. Accessed: Jan. 19, 2019. doi. 10.6620/ZS.2018.57-07.

PARIN, M. A., et al. Aspectos económicos del procesamiento y uso de ensilados de pescado. In: Figueroa V, Sánchez M editors. Tratamiento y utilización de residuos de origen animal, pesquero y 
alimenticio en la alimentación animal. Estudio FAO Producción y Sanidad Animal. Roma, Italia.; 1997. p.41-64.

PETERS, D., et al. Determinación del nivel óptimo de sustitución de la harina de pescado por harina de hidrolizado de plumas en el alimento para tilapia roja, Oreochromis sp. Ciencia. v.12, n.1, p. 13-24, 2004. Available from: $<$ https://produccioncientificaluz.org/index.php/ ciencia/article/view/9205/9194>. Accessed: Jan. 19, 2019.

TACON, A. Feed ingredients for warm water fish: fish meal and other processed feedstuffs. FAO Fisheries Circular. No. 856 FAO, Rome, Italy; 1993.
TACON, A. Trends in Global Aquaculture and Aquafeed Production: 2000-2017. Reviews in Fisheries Science and Aquaculture. v.28, n.1, p.43-56. 2018. Available from: <https:// doi.org/DOI:10.1080/23308249.2019.1649634>. Accessed: Mar. 21, 2020. doi: 10.1080/23308249.2019.1649634

ZHOU, X. Brief overview of world aquaculture production: an update with latest available 2017 global production data. FAO Aquaculture Newsletter, v.60, p.6-8, 2019. Available from: $<$ https://search.proquest.com/openview/b417cf597958a8df9361 b1341 cdb7def $/ 1$ ?pq-origsite $=$ gscholar\&cbl $=237326>$. Accessed: Mar. 21, 2020. 